\title{
Optimization of guava juice wastewater electrochemical treatment
}

\author{
Otimização do tratamento eletroquímico do efluente de suco de goiaba \\ Optimización del tratamiento electroquímico del efluente de jugo de guayaba
}

Received: 01/29/2021 | Reviewed: 02/05/2021 | Accept: 02/15/2021 | Published: 02/21/2021

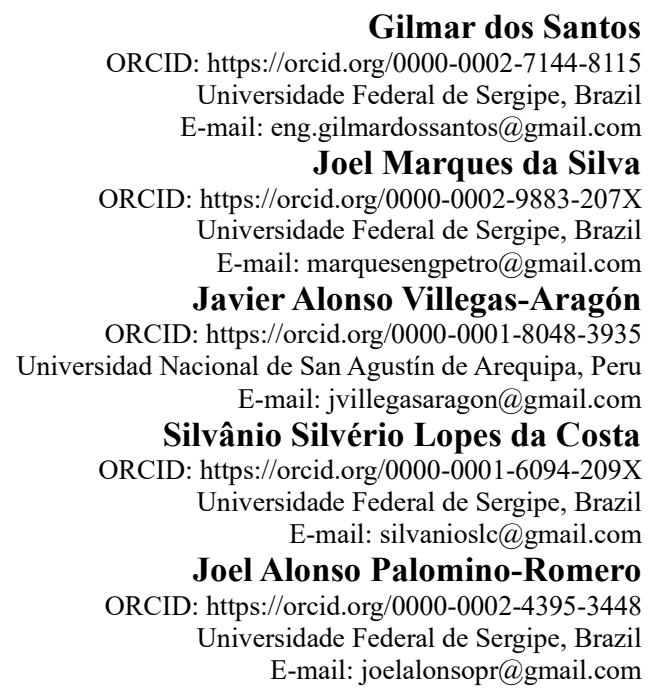

\begin{abstract}
Wastewater from guava juice production was treated by two electrochemical processes: Electroflotation (EF) and Electrocoagulation (EC). Using Box-Behnken experimental design, these processes were optimized in order to find the values of treatment time, initial $\mathrm{pH}$ and current density that lead to the maximum chemical oxygen demand (COD) removal efficiencies. Aluminum electrodes were used in EC treatment and an iron cathode and a ruthenium dioxide / titanium dioxide anode were applied in EF treatment. EC treatment resulted in maximum COD removal of $60 \%$, when treating the wastewater for 40 minutes, with initial $\mathrm{pH} 4.5$ and current density of $35 \mathrm{~A} / \mathrm{m}^{2}$. On the other hand, EF only removed $25 \%$ of the wastewater COD (treatment time 40 minutes, initial pH 7.0 and current density $45 \mathrm{~A} / \mathrm{m}^{2}$ ). Aluminum sulfate addition improved the wastewater conductivity, lowering electricity consumption rates. Moreover, the treatment combining EF and this chemical coagulant lead to better results than the ones found when using EF alone. Keywords: Electroflotation; Electrocoagulation; Aluminum sulphate.
\end{abstract}

\section{Resumo}

O efluente gerado na produção de suco de goiaba foi tratado por dois processos eletroquímicos: Eletroflotação (EF) e Eletrocoagulação (EC). Utilizando o planejamento experimental Box-Behnken, estes processos foram otimizados para poder encontrar os valores de tempo de tratamento, $\mathrm{pH}$ inicial e densidade de corrente que conduzam à obtenção da máxima remoção da demanda química de oxigênio (DQO). No processo de EC foram empregados eletrodos de alumínio, enquanto que no processo de EF foram utilizados um cátodo de ferro e um ânodo de dióxido de titânio / dióxido de rutênio. O tratamento do efluente por EC resultou em eficiência máxima de $60 \%$ na redução da DQO, com tempo de tratamento de 40 minutos, $\mathrm{pH}$ inicial de 4,5 e densidade de corrente de $3,5 \mathrm{~mA} / \mathrm{cm}^{2}$. Por outro lado, no processo de EF foi obtida uma remoção de DQO de $25 \%$ ao se tratar o efluente por 40 minutos, com pH inicial de 7,0 e aplicandose uma densidade de corrente de $4,5 \mathrm{~mA} / \mathrm{cm}^{2}$. A adição do sulfato de alumínio melhorou a condutividade do efluente, reduzindo a demanda elétrica. A combinação do processo de EF com este coagulante químico conduziu à obtenção de melhores resultados se comparados aos obtidos unicamente pelo processo de EF.

Palavras-chave: Eletroflotação; Eletrocoagulação; Sulfato de alumínio.

\section{Resumen}

El efluente resultante de la producción de jugo de guayaba fue tratado por los procesos de electrocoagulación (EC) y electroflotación (EF). Utilizando la planificación experimental Box-Behnken, estos procesos se optimizaron para poder encontrar los valores de tiempo de tratamiento, $\mathrm{pH}$ inicial y densidad de corriente que lleven a obtener la máxima reducción de la demanda química de oxigeno (DQO). En el proceso de EC se utilizaron electrodos de aluminio, mientras que en el proceso de EF utilizaron un cátodo de hierro y un ánodo de dióxido de titanio / dióxido de rutenio. El efluente 
tratado por EC obtuvo una eficacia máxima de reducción de la DQO de $60 \%$, con tiempo de tratamiento de 40 minutos, $\mathrm{pH}$ inicial de 4,5 y densidad de corriente de $3,5 \mathrm{~mA} / \mathrm{cm}^{2}$. Por otro lado, con el proceso de $\mathrm{EF}$ se obtuvo una reducción de DQO de $25 \%$ cuando se trató el efluente por 40 minutos, con $\mathrm{pH}$ inicial de 7,0 y aplicando-se una densidad de corriente de $4,5 \mathrm{~mA} / \mathrm{cm}^{2}$. La adición de sulfato de aluminio mejoró la conductividad del efluente, disminuyendo la demanda eléctrica. La combinación del proceso de EF con este coagulante químico llevó a obtener mejores resultados, si los comparamos a los obtenidos sólo por el proceso de EF.

Palabras clave: Electroflotación; Electrocoagulación; Sulfato de aluminio.

\section{Introduction}

Industries are one of the main sources of wastewater generation. Industrial activities include various operations that use large volumes of water, such as floor and machines washing, heating, cooling and cooking processes. As a result, high amounts of wastewater carrying varied contaminants are usually generated by these locations.

In the case of food and beverage industries, it is remarkable the generation of large amounts of wastewater that, although usually are free from toxic pollutants, present high levels of organic loads (Alvarez et al., 2011). Normally, biological processes are chosen to treat these types of wastewaters and others that, similarly, carry considerable amounts of organic matter. In these processes, microorganisms degrade organic compounds in the presence or absence of oxygen, depending on the used technique. However, as highlighted by Drogui et al. (2008), although generally being an economically viable and efficient option, biological techniques of treatment demand large areas and long detention times, what can make their implementation impracticable.

Amongst the most compact and with shorter detention time alternatives of wastewater treatment are the electrocoagulation (EC) and the electroflotation (EF), physical-chemical techniques that have been the focus of a series of researches in varied areas throughout the last decades. These processes are based on the principle of electrolysis, which consists in breaking substances through the use of electricity. In an electrolytic reactor, ions are changed between electrodes when occur the passage of an electric current (Sahu et al., 2014). Depending on the material of the electrodes, different processes will provide the separation and posterior removal of the pollutants present in the wastewater.

In EF process, bubbles of oxygen and hydrogen are released in the anode and cathode of an electrolytic cell, respectively, due to water electrolysis, following the reactions shown in Equations (1) and (2) (Wang et al., 2010). The generated bubbles collide and entrap particles of contaminants present in the wastewater, carrying them to the upside of the reactor.

$$
\begin{aligned}
& 2 \mathrm{H}_{2} \mathrm{O} \rightarrow 4 \mathrm{H}^{+}+\mathrm{O}_{2} \uparrow+4 \mathrm{e}^{-} \\
& 4 \mathrm{e}^{-}+4 \mathrm{H}_{2} \mathrm{O} \rightarrow 2 \mathrm{H}_{2} \uparrow+4 \mathrm{OH}^{-}
\end{aligned}
$$

The process known as EC, on the other hand, is characterized by the generation of metallic ions from the dissolution of the anode of the electrolytic cell. These ions posteriorly hydrolyze and form coagulant agents that destabilize colloidal particles in the wastewater, enabling the formation of flocs that can sediment to the bottom of the reactor or float due to the bubbles generated.

According to Sahu et al. (2014), in addition to oxygen and hydrogen bubbles evolution, the reactions shown in Equations (3) and (4) occur in the anode and cathode respectively. $\mathrm{M}$ depends on the material that constitute the anode.

$$
\begin{aligned}
& \left.\mathrm{M}_{(\mathrm{s})} \rightarrow \mathrm{M}_{(\mathrm{aq})}\right)^{\mathrm{n}}+\mathrm{ne}^{-} \\
& \mathrm{M}_{(\mathrm{aq})}{ }^{\mathrm{n+}}+\mathrm{ne}^{-} \rightarrow \mathrm{M}_{(\mathrm{s})}
\end{aligned}
$$

A series of factors can affect EC and EF processes, some of the most important being: current density, time of electrolysis, initial $\mathrm{pH}$, electrodes material, wastewater conductivity, and inter-electrode spacing. 
$\mathrm{EC}$ and $\mathrm{EF}$ have a series of advantages, such as the simplicity of the required equipment, the low generation of sludge and the need of relatively small areas. In addition, these processes have showed high efficiency when applied to a varied set of wastewaters. In this work, these electrochemical techniques were applied to the treatment of wastewater generated by fruit juice production, which notably carries high amounts of organic matter and suspended solids. The $\mathrm{pH}$, the current density and the treatment time were varied in sets of experiments planned using the Box-Behnken experimental design. The results obtained were used to optimize the chemical oxygen demand (COD) removal efficiency of both EF and EC treatments. This paper was based on the principle of the need to bring knowledge produced in academia to society, with wide applicability in problem solving, integrating science, society and technology (Pereira et al., 2018).

\section{Methodology}

\subsection{Physical-Chemical Analysis}

The $\mathrm{pH}$ of untreated and treated wastewater was determined using a $\mathrm{pH}$ meter (Hanna Edge) and the turbidity was measured with a turbidimeter (Orion AQ 3010). A benchtop multiparameter was used to measure the conductivity (AZ model 86505 ) and both Total Organic Carbon and Total Nitrogen were determined with a TOC and TN analyzer (Analytic Jena model NC 3100).

The chemical oxygen demand (COD), biochemical oxygen demand (BOD), volatile solids (VS), total solids (TS) and total suspended solids (TSS) concentrations were determined following the Standard Methods for the Examination Water and Wastewater (APHA, 2005).

\subsection{Wastewater}

The wastewater treated in this work was collected from a Brazilian fruit juice industry. Such wastewater is mainly produced by the cleaning processes that take place in the factory, such as the washing of fruits, equipment and factory floor.

According to Akbay et al. (2018), typical fruit juice industries generate around $10 \mathrm{~L}$ of wastewater per liter of juice. In addition, such wastewater has low $\mathrm{pH}$, high levels of $\mathrm{COD}$, unbalanced amounts of nutrients and high concentration of suspended and dissolved solids (Can, 2014).

Table 1 presents the physical-chemical characterization of the guava juice production wastewater used in this work. 
Research, Society and Development, v. 10, n. 2, e41910212474, 2021

(CC BY 4.0) | ISSN 2525-3409 | DOI: http://dx.doi.org/10.33448/rsd-v10i2.12474

Table 1. Physical-chemical characterization of guava juice wastewater.

\begin{tabular}{ccc}
\hline Parameter & Range of Values & Unit \\
\hline pH & $4.79-5.07$ & - \\
Turbidity & $119-201$ & $\mathrm{NTU}$ \\
Conductivity & $367-380$ & $\mu \mathrm{S} / \mathrm{cm}$ \\
COD & $2,582-3,685$ & $\mathrm{mg} / \mathrm{L}$ \\
BOD & $460-854$ & $\mathrm{mg} / \mathrm{L}$ \\
TOC & $178-429$ & $\mathrm{mg} / \mathrm{L}$ \\
TN & $18-23$ & $\mathrm{mg} / \mathrm{L}$ \\
TS & $760-1823$ & $\mathrm{mg} / \mathrm{L}$ \\
VS & $713-1560$ & $\mathrm{mg} / \mathrm{L}$ \\
TSS & $70-472$ & $\mathrm{mg} / \mathrm{L}$ \\
\hline
\end{tabular}

Source: Authors.

The samples of wastewater treated in this work were collected in the days of guava juice production and were taken from the final section of the channel responsible for canalizing all the wastewater from the factory to the outside area.

\subsection{Reactor}

The electrolytic cell used as batch reactor to treat the fruit juice wastewater and its electrochemical system is illustrated in Figure 1. A $600 \mathrm{~mL}$ beaker and two rectangular metal plates, which acted as electrodes, constituted the system.

Figure 1. Schematic diagram of the experimental configuration of the electrochemical processes.

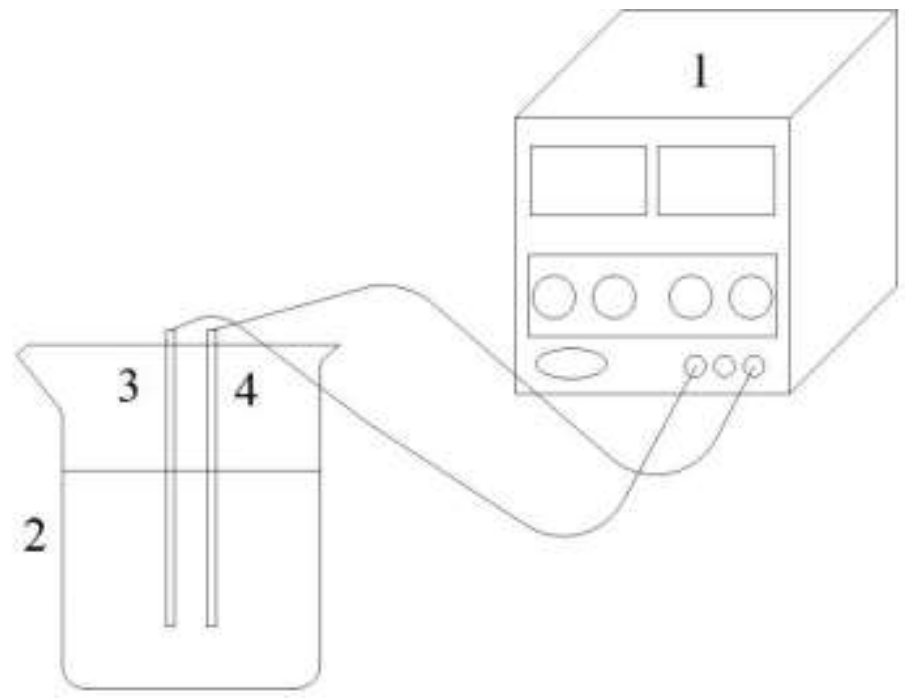

\section{Power Source}

\section{Electrolytic}

Cell

\section{Anode}

4 Cathode

Source: Authors. 
The spacing inter-electrode was fixed in $1.0 \mathrm{~cm}$. According to the process studied, different combinations of electrodes were employed. In the case of EF process, $\mathrm{a} \mathrm{TiO}_{2}-\mathrm{RuO}_{2}$ anode and an iron cathode were used. On the other hand, to assess EC performance, both electrodes were made of aluminum. During each run the electrodes were connected to a continuous current power supply model ITFA 5000, which operates in the range of 0 to $32 \mathrm{~V}$ and 0 to $3 \mathrm{~A}$.

Box-Behnken experimental design was used to plan the tests. The factors chosen were $\mathrm{pH}$, current density and treatment time, which were varied in three different levels. The determination of the value levels was fixed taking into account preliminary experiments, the original characteristics of the wastewater and the literature.

Comninellis and Chen (2010) explain that values of $\mathrm{pH}$ that are very low or values higher than 10 lead to the reduction of the coagulation process when using aluminum electrodes. This fact is related to the predominance of species with no coagulation effect, such as $\mathrm{Al}_{3}{ }^{+}$and $\mathrm{Al}(\mathrm{OH})_{4}{ }^{-}$in the mentioned conditions. According to Chen et al. (2000) the range of pH between 4 and 9 is more effective to the COD reduction. Out of this range, there is a low concentration of $\mathrm{Al}(\mathrm{OH})_{3}$, species that acts in the removal of the soluble part of the COD.

Due to the exposed facts, the lower value of $\mathrm{pH}$ was defined as being 4.5 , which is very close to the original $\mathrm{pH}$ of the wastewater. Intending to assess the effectiveness of the processes in neutral and basic conditions, it was chosen to work with 9.5 as superior level and, thereafter, the $\mathrm{pH} 7$ was defined as medium level.

The power supply characteristics and the original conductivity of the wastewater were taken into account when choosing the maximum value of current density. The lower level of this factor was fixed as being $25 \mathrm{~A} / \mathrm{m}^{2}$, value suggested by Comninellis and Chen (2010) and observed as being a value that induced the generation of a considerable amount of bubbles, especially in the case of EF.

The order and conditions of the tests were determined using the software Design Expert. Adopting 5 as the quantity of central points, the total amount of tests to optimize the electrochemical treatments was defined as being 17 for EC and 17 for the EF. The test results were used as input data in the software Design Expert to generate three response surfaces for EC and three for EF. Such graphics show the interaction amongst the factors time, $\mathrm{pH}$ and current density and the response, which is the COD reduction efficiency. The mentioned software was also used to find the optimal conditions for the electrochemical treatment. These conditions reflected the maximization of COD reduction and the minimization of the operational cost, which are mainly related with the electrical consumption and the addition of chemical products.

In each run, at room temperature, $400 \mathrm{~mL}$ of wastewater were submitted to the passage of an electrical current, determined according to the fixed current density. The $\mathrm{pH}$ of the samples was adjusted by using solutions of $0.1 \mathrm{M} \mathrm{H}_{2} \mathrm{SO}_{4}$ and 1.0 $\mathrm{M} \mathrm{NaOH}$. To minimize the effects of the passivation phenomenon, periodically the electrodes were put in a solution containing sodium chloride and were submitted to the passage of an electrical current. According to Kuokkanen et al. (2013), the chloride ions released destroy the passivation layer formed in the electrodes, avoiding the amplification of such phenomenon.

\subsection{Aluminum Sulfate}

The effects of the addition of aluminum sulfate $\left(\mathrm{Al}_{2}\left(\mathrm{SO}_{4}\right)_{3} \cdot 16 \mathrm{H}_{2} \mathrm{O}\right)$ to the electrochemical treatment of the studied wastewater were also assessed. The most favorable operational conditions determined in the previous part of the research were defined as the ones to be used in a new series of tests, in which different concentrations of this chemical coagulant were added to the wastewater. The mixture coagulant-wastewater was homogenized and after that the electrochemical treatment was made as described previously. 


\section{Results and Discussion (can be separated or together) (TNR font 12 - left aligned)}

\subsection{EC Optimization}

Table 2 shows the operational conditions used in the 17 runs of EC planned with Box-Behnken Experimental Design, as well as the COD reduction efficiency obtained in each case. The values of the levels of the factor time were 10, 25 and 40 minutes, which were defined after preliminary tests.

The runs number 2, 14 and 17 were the ones with the best results. COD was reduced by $58 \%, 60 \%$ and $56 \%$ and turbidity removal reached $77 \%, 88 \%$ and $77 \%$ respectively.

Such COD removal values are similar to the ones found in the work by Can (2014), in which COD was reduced by $59.1 \%$ when treating fruit juice wastewater with aluminum electrodes and with initial $\mathrm{pH}$ of 5.5. Akbay et al. (2018) also treated this kind of wastewater with initial $\mathrm{pH}$ of 5.5 and an aluminum anode, obtaining $66 \%$ of COD efficiency removal, value that is also close to the one found in this work.

Table 2. Box-Behnken experimental design - EC.

\begin{tabular}{ccccc}
\hline Run & Time (min) & pH & Current Density $\left(\mathbf{A} / \mathbf{m}^{2}\right)$ & $\begin{array}{c}\text { COD Reduction } \\
(\%)\end{array}$ \\
\hline 1 & 25 & 4.5 & 25 & 15 \\
2 & 40 & 7.0 & 45 & 58 \\
3 & 40 & 9.5 & 35 & 38 \\
4 & 10 & 9.5 & 35 & 8 \\
5 & 40 & 7.0 & 25 & 35 \\
$6^{*}$ & 25 & 7.0 & 35 & 29 \\
7 & 10 & 7.0 & 25 & 10 \\
8 & 10 & 4.5 & 35 & 6 \\
$9 *$ & 25 & 7.0 & 35 & 23 \\
10 & 25 & 9.5 & 45 & 37 \\
11 & 10 & 7.0 & 45 & 15 \\
$12^{*}$ & 25 & 7.0 & 35 & 20 \\
13 & 25 & 9.5 & 25 & 60 \\
14 & 40 & 4.5 & 35 & 24 \\
$15^{*}$ & 25 & 7.0 & 35 & 23 \\
$16^{*}$ & 25 & 7.0 & 35 & 56 \\
17 & 25 & 4.5 & 45 & \\
\hline & $*$ Reptitions in the central point. Source: Authors. & \\
\hline
\end{tabular}

On the other hand, the runs of number 4, 7 and 8 showed the least favorable results. These tests had the duration of just 10 minutes, what can be indicated as a major factor for the low values of COD reduction obtained. The run of number 11 had the same duration of the ones previously mentioned but, probably due to the higher current density applied, showed a better performance than those.

The data obtained from the runs were fitted to a linear model. Due to the wide range of values of the response, a square root transformation was also applied. Equation (6) shows the final model, in which $\mathrm{A}, \mathrm{B}$ and $\mathrm{C}$ are the time, $\mathrm{pH}$ and current density, respectively, and $\mathrm{R}$ is the COD reduction. 
$\sqrt{ } \mathrm{R}=-0,73+0,13 \times A-0,10 \times B+0,09 \times C$

Figure 2 shows the graphic of the predicted values and the actual values of the response.

Figure 2. Predicted and actual values of the response - EC.
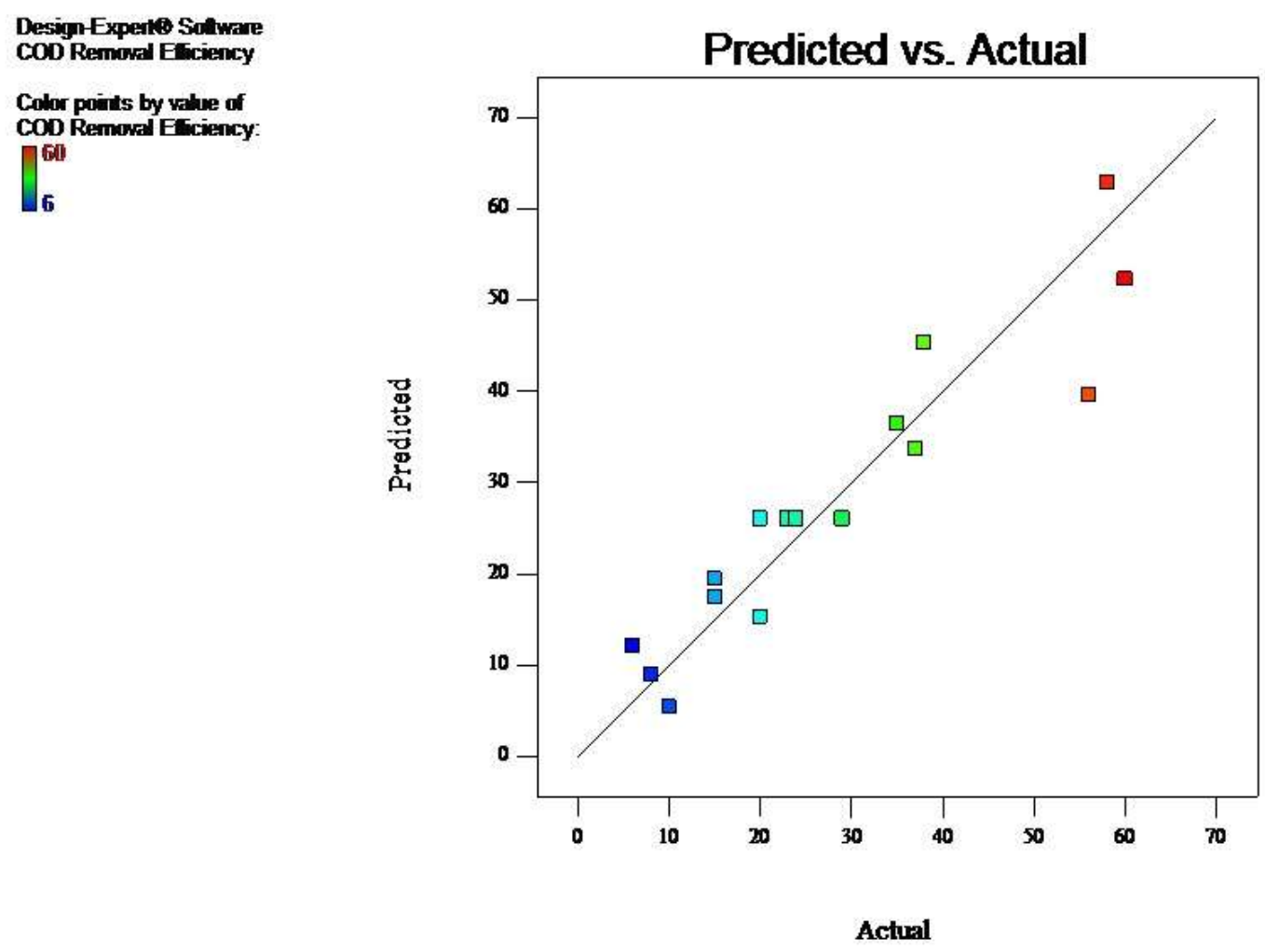

Source: Authors.

Using the adjusted polynomial, the response surfaces shown in Figures 3, 4 and 5 were generated. It is possible to observe that the increase of time has positive effects on the COD reduction, what was already verified in the preliminary tests. In addition, the influence of the current density on the COD reduction reflected the expectations. This operational condition, according to Comninellis and Chen (2010), is responsible for the coagulant dosage, since the amount of electrical current that passes through the electrolytic solution directly impacts on the anode dissolution. Thus, an elevation in the current density should lead to an increase of COD removal, since a higher amount of coagulant is available to perform the treatment of the wastewater. 
Figure 3. Effects of current density and time on COD removal efficiency.

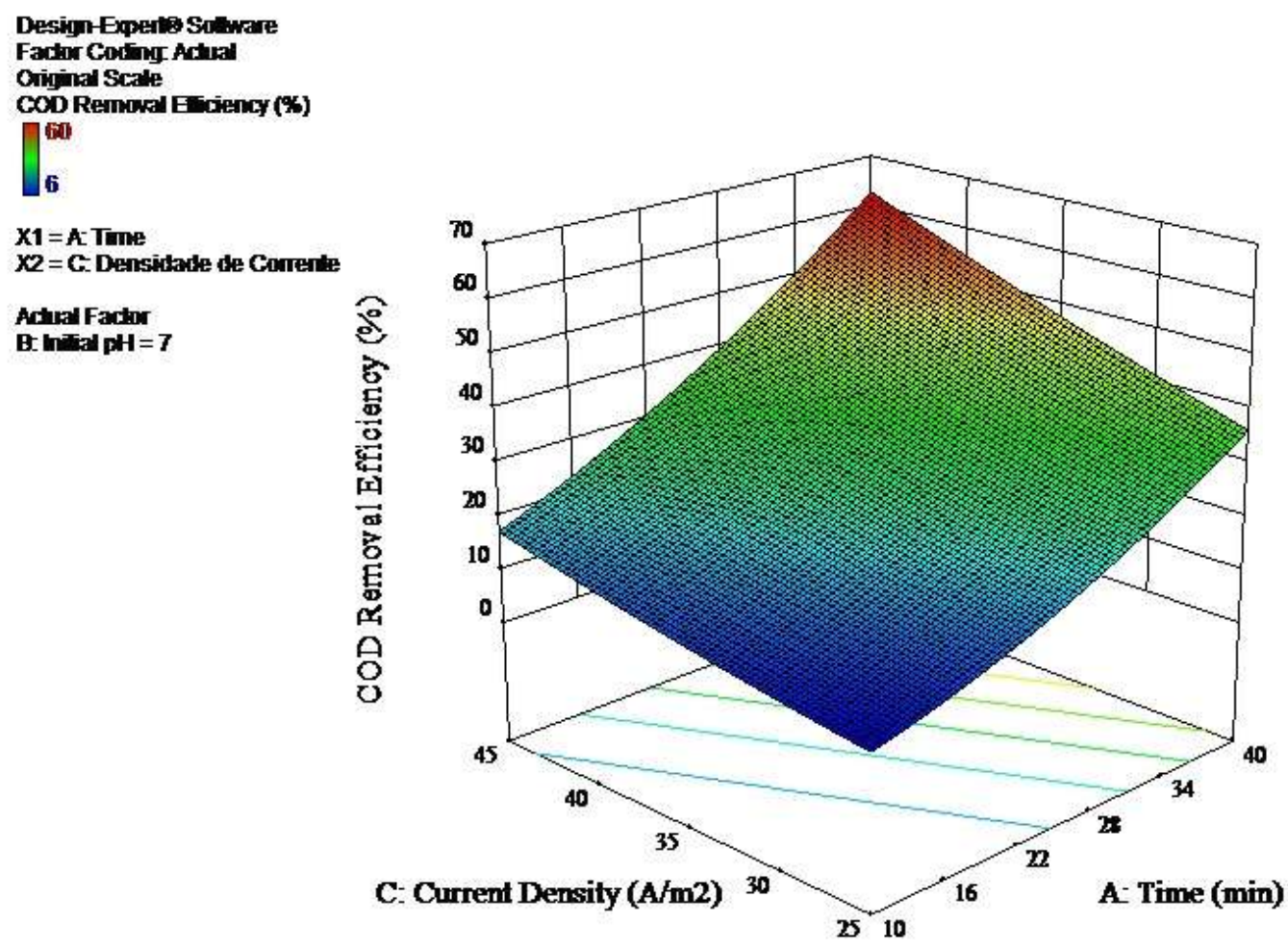

Source: Authors.

However, there is a point in which this behavior stops being noticed. Moussa et al. (2017) explain that the use of high current density values can lead to a decrease of the current efficiency. In addition, in this situation, there is a loss of energy due to the heating of the liquid being treated. Although this scenario was not observed in this work, it shows the importance of analyzing different values of current densities to find the most viable condition, since the use of high values of this parameter lead to the increase of electrical consumption and, therefore, operational cost. 
Figure 4. Effects of initial $\mathrm{pH}$ and time on COD removal efficiency.

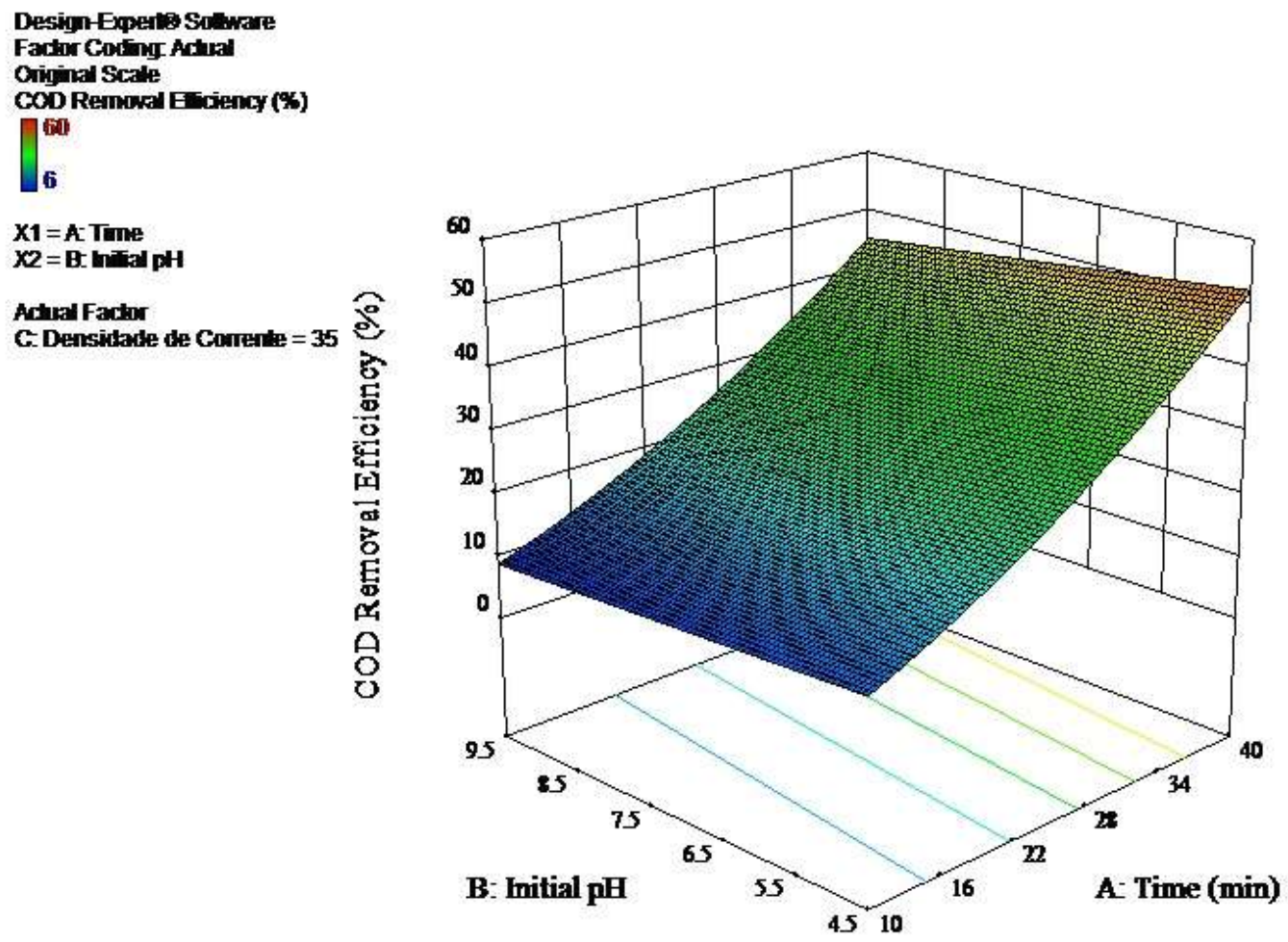

Source: Authors.

On the other hand, it is noticeable that higher values of $\mathrm{pH}$ were less favorable to the EC performance. Akbay et al. (2018) also verified such occurrence in their work. They noticed that values of $\mathrm{pH}$ higher than 5.5, which was the original $\mathrm{pH}$ of the wastewater, decreased the COD removal efficiency of the treatment. According to Chen (2004), oxygen bubbles have their size increased with the increase of $\mathrm{pH}$. In addition, this operational condition also affects the current efficiency and the solubility of the generated metallic hydroxides (Chen and Hung 2007). One or more of these phenomena may have a role in the reduction of the EC performance when applied to the studied wastewater. 
Figure 5. Effects of initial $\mathrm{pH}$ and current density on COD removal efficiency.

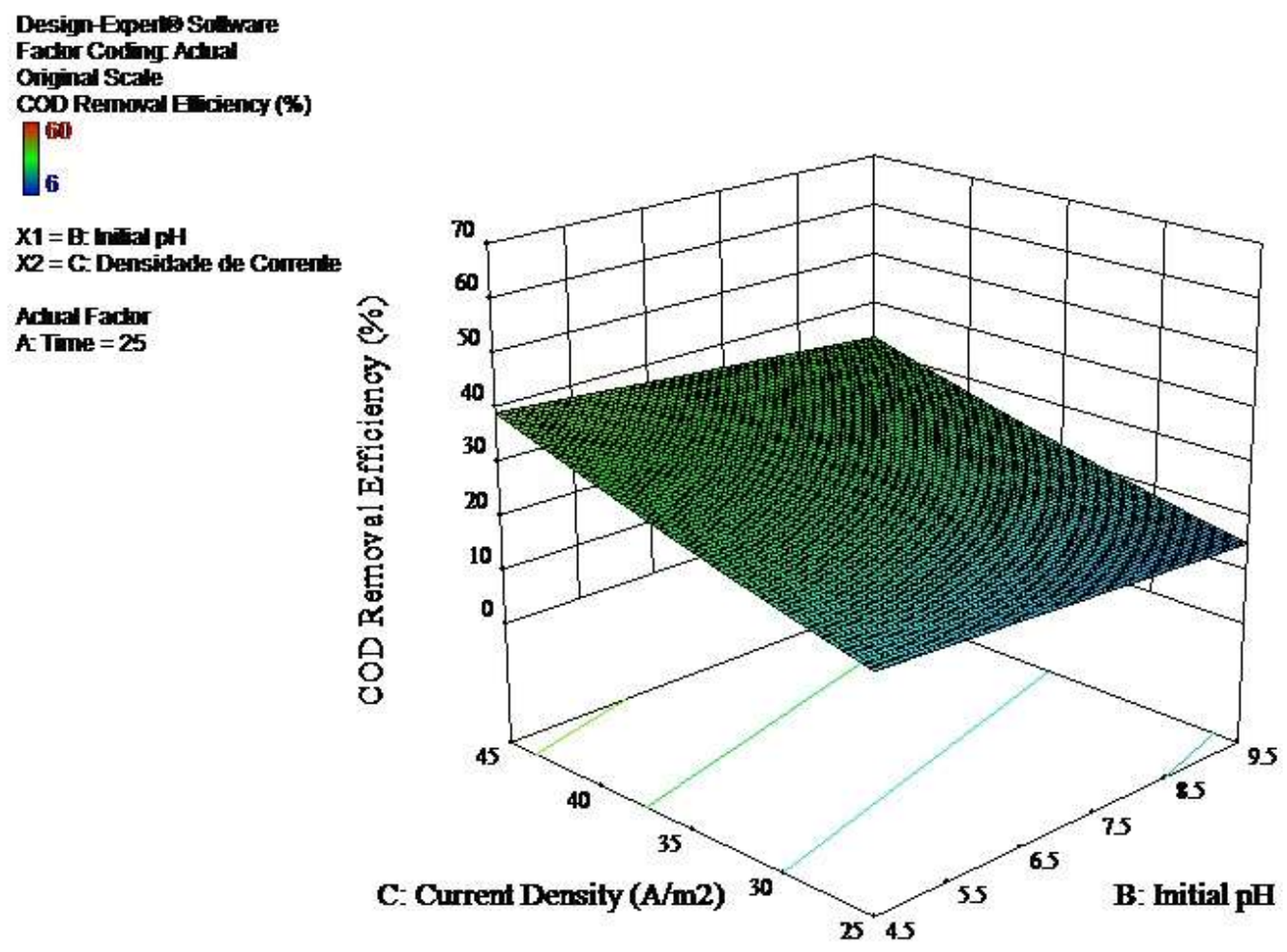

Source: Authors.

To optimize the process via Design Expert, different criteria were defined. Such criteria, presented below, take into account not only the maximization of the COD reduction but also the minimization of operational costs related with the electrical consumption.

Criteria 1: maximization of COD reduction (above 55\%), with no restrictions regarding the factors;

Criteria 2: maximization of COD reduction (above 55\%) and minimization of time;

Criteria 3: maximization of COD reduction (above 55\%) and minimization of current density;

Criteria 4: maximization of COD reduction (above 55\%) and minimization of time and current density.

The optimal conditions found (Table 3) reflect the tendency presented by the linear model applied, in which the increase of the factors leads to the increase of the response. Such tendency, however, is the opposite in the case of the $\mathrm{pH}$, once, as already mentioned, the lower value of this factor was the most favorable. 
Research, Society and Development, v. 10, n. 2, e41910212474, 2021

(CC BY 4.0) | ISSN 2525-3409 | DOI: http://dx.doi.org/10.33448/rsd-v10i2.12474

Table 3. Optimized values - EC.

\begin{tabular}{ccccc}
\hline \multirow{2}{*}{ Criteria } & \multicolumn{3}{c}{ Operational Conditions } & $\begin{array}{c}\text { Expected COD } \\
\text { Reduction (\%) }\end{array}$ \\
\cline { 2 - 5 } & $\mathbf{p H}$ & Time (min) & Current Density $\left(\mathbf{A} / \mathbf{m}^{2}\right)$ & \\
\hline 1 & 4.6 & 38.1 & 45 & 62.5 \\
2 & 4.5 & 36.5 & 45 & 60.0 \\
3 & 4.5 & 40.0 & 40 & 59.9 \\
4 & 4.5 & 38.0 & 42 & 58.9 \\
\hline
\end{tabular}

Source: Authors.

\subsection{EF Optimization}

Table 4 presents all the EF tests made in accordance to the Box-Behnken Experimental Design. As observed in the preliminary tests, EF process, in general, acted as a way less efficient treatment for reducing the COD of the guava juice wastewater when comparing to EC process. The higher COD removal efficiency obtained by EF process were 24 and $25 \%$, in the runs number 17 and 4, respectively. Close results were found in the tests number 1,2 and 12. Similarly to EC, the lowest COD reduction levels were obtained in the runs with shorter duration $(5,6,7$ and 1$)$, what shows once more the impact of the time factor in the electrochemical treatment. 
Table 4. Box-Behnken experimental design - EF.

\begin{tabular}{|c|c|c|c|c|}
\hline Run & Time (min) & pH & Current Density $\left(\mathbf{A} / \mathbf{m}^{2}\right)$ & $\begin{array}{c}\text { COD Reduction } \\
(\%)\end{array}$ \\
\hline 1 & 40 & 7 & 25 & 23 \\
\hline 2 & 25 & 9.5 & 25 & 23 \\
\hline 3 & 25 & 4.5 & 25 & 20 \\
\hline 4 & 40 & 7 & 45 & 25 \\
\hline 5 & 10 & 7 & 45 & 17 \\
\hline 6 & 10 & 7 & 25 & 16 \\
\hline 7 & 10 & 9.5 & 35 & 15 \\
\hline $8^{*}$ & 25 & 7 & 35 & 20 \\
\hline 9 & 25 & 4.5 & 45 & 20 \\
\hline 10 & 10 & 4.5 & 35 & 13 \\
\hline $11^{*}$ & 25 & 7 & 35 & 19 \\
\hline 12 & 40 & 9.5 & 35 & 23 \\
\hline 13 & 40 & 4.5 & 35 & 22 \\
\hline $14^{*}$ & 25 & 7 & 35 & 20 \\
\hline $15^{*}$ & 25 & 7 & 35 & 18 \\
\hline $16^{*}$ & 25 & 7 & 35 & 18 \\
\hline 17 & 25 & 9.5 & 45 & 24 \\
\hline
\end{tabular}

*Repetitions in the central point. Source: Authors.

In regards to the turbidity removal, it can be observed that, differently from the tendency shown by the other electrochemical treatment, in the case of the EF the best result attained was not found in the same run that presented the higher COD reduction efficiency. The higher levels of turbidity removal were reached in runs number 9,4 and 1 , that removed this parameter by $60 \%, 56 \%$ and $56 \%$, respectively. From the obtained results, it can be noted that the turbidity removal is compromised by the increase of the initial $\mathrm{pH}$.

In this case, due to the characteristics of the data, a quadratic model was used to fit the outcome of the tests, which is shown in Equation (7). A, B and $\mathrm{C}$ represent the factors time, $\mathrm{pH}$ and current density, respectively, and $\mathrm{R}$ is the COD removal efficiency.

$$
R=33,51+0,51 \times A+0,5 \times B-1,63 \times C-4,91 \times 10^{-3} \times A^{2}+0,02 \times C^{2}
$$

Figure 6 shows the values predicted by the model and the actual values of the response. The response surfaces generated are shown in Figures 7, 8 and 9. The surfaces that include the factor time, as can be noted, display the tendencies observed in the preliminary tests. Moreover, time is the most influential factor for the electrochemical treatment efficiency, being the main responsible for the fluctuation of the COD reduction efficiency values. The increase of treatment time rises the probability of collisions between bubbles and pollutant particles, increasing the rate of particles that adhere to bubbles and, therefore, the amount of removed COD from the wastewater. 
Figure 6. Predicted and actual values of the response $-\mathrm{EF}$.
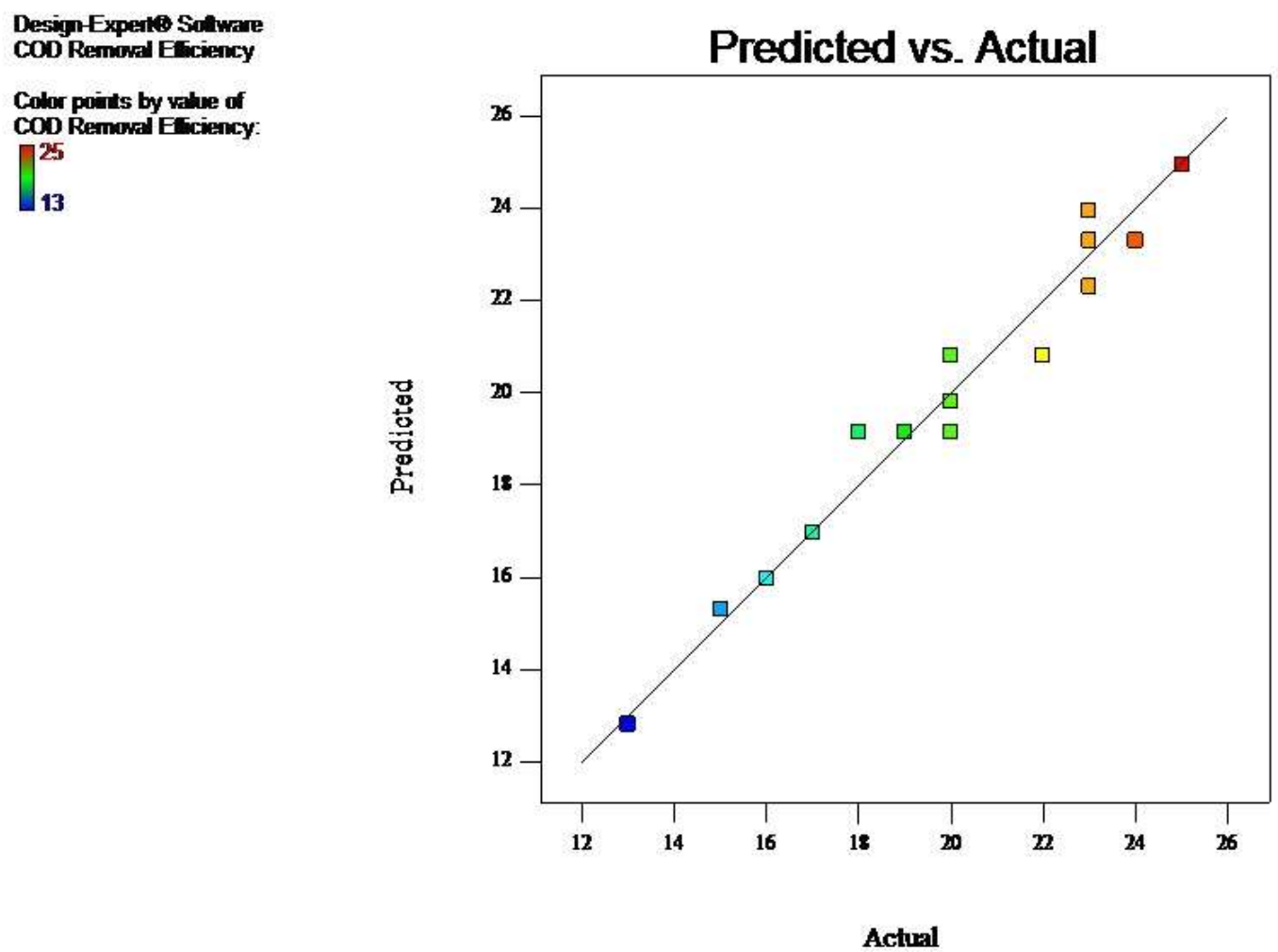

Source: Authors.

When assessing the impact provoked by the variation of $\mathrm{pH}$, it is possible to observe that EF reacts in a way that is opposite to the one shown by EC. This may indicate that, while lower $\mathrm{pH}$ values favored the coagulation phenomenon in EC, neutral and more basic conditions had a better impact over the characteristics of the bubbles formed in the case of EF, which are the main responsible for the removal of pollutants in this case. 
Figure 7. Effects of initial $\mathrm{pH}$ and time on COD removal efficiency.

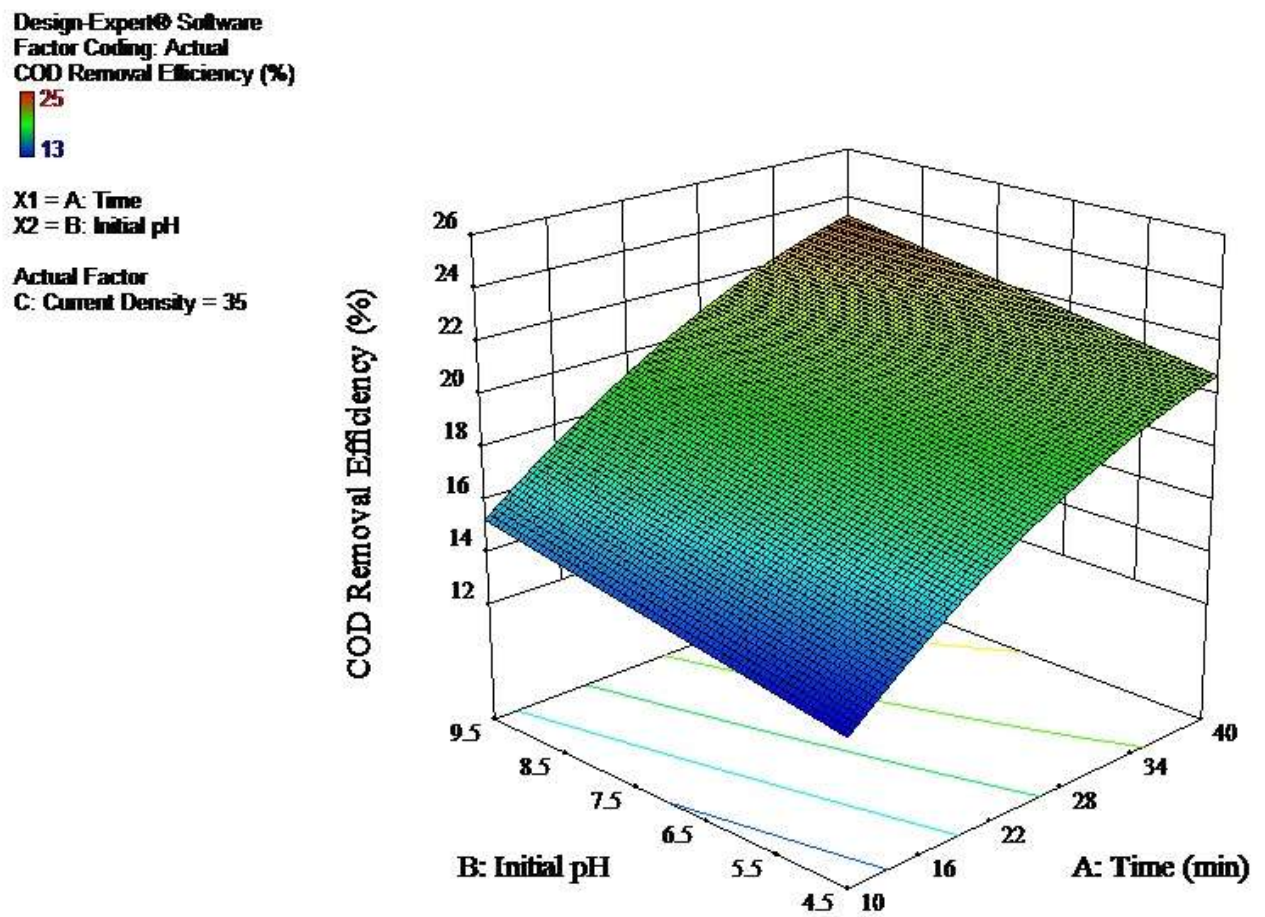

Source: Authors.

Figure 8. Effects of initial current density and time on COD removal efficiency.

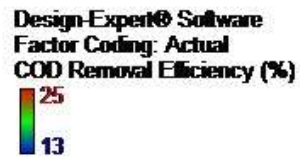

$\mathbf{X 1}=\mathbf{A} \cdot T_{\mathrm{me}}$

X2 $=$ C: Cument Densily

Actual Factor

B: hitial pH $=7$

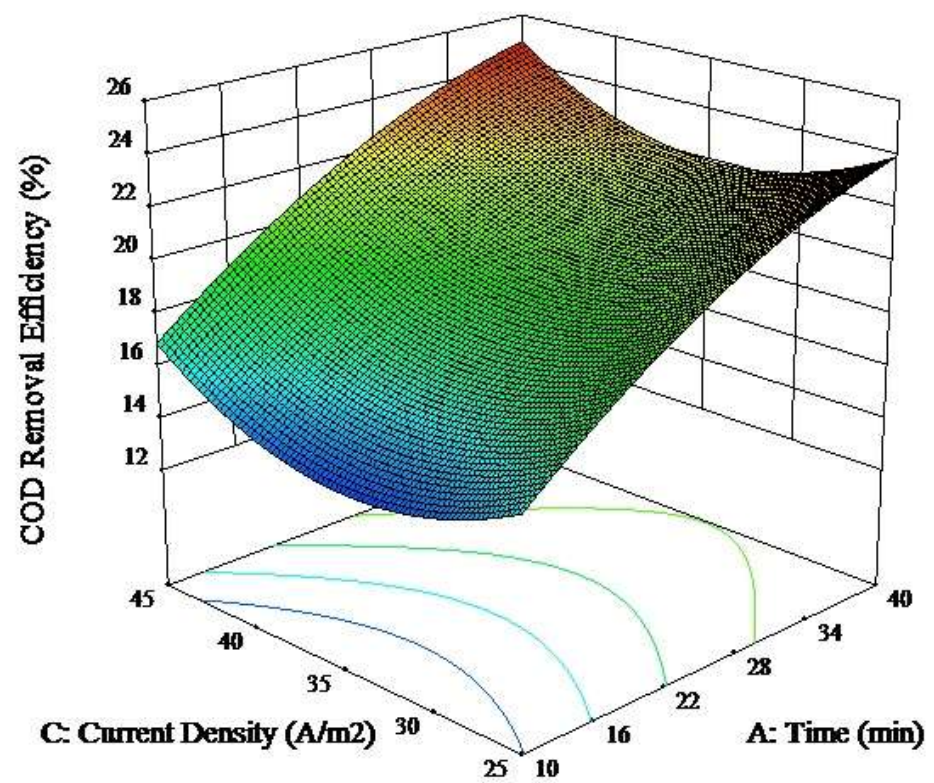

Source: Authors. 
Figure 9. Effects of initial $\mathrm{pH}$ and current density on COD removal efficiency.
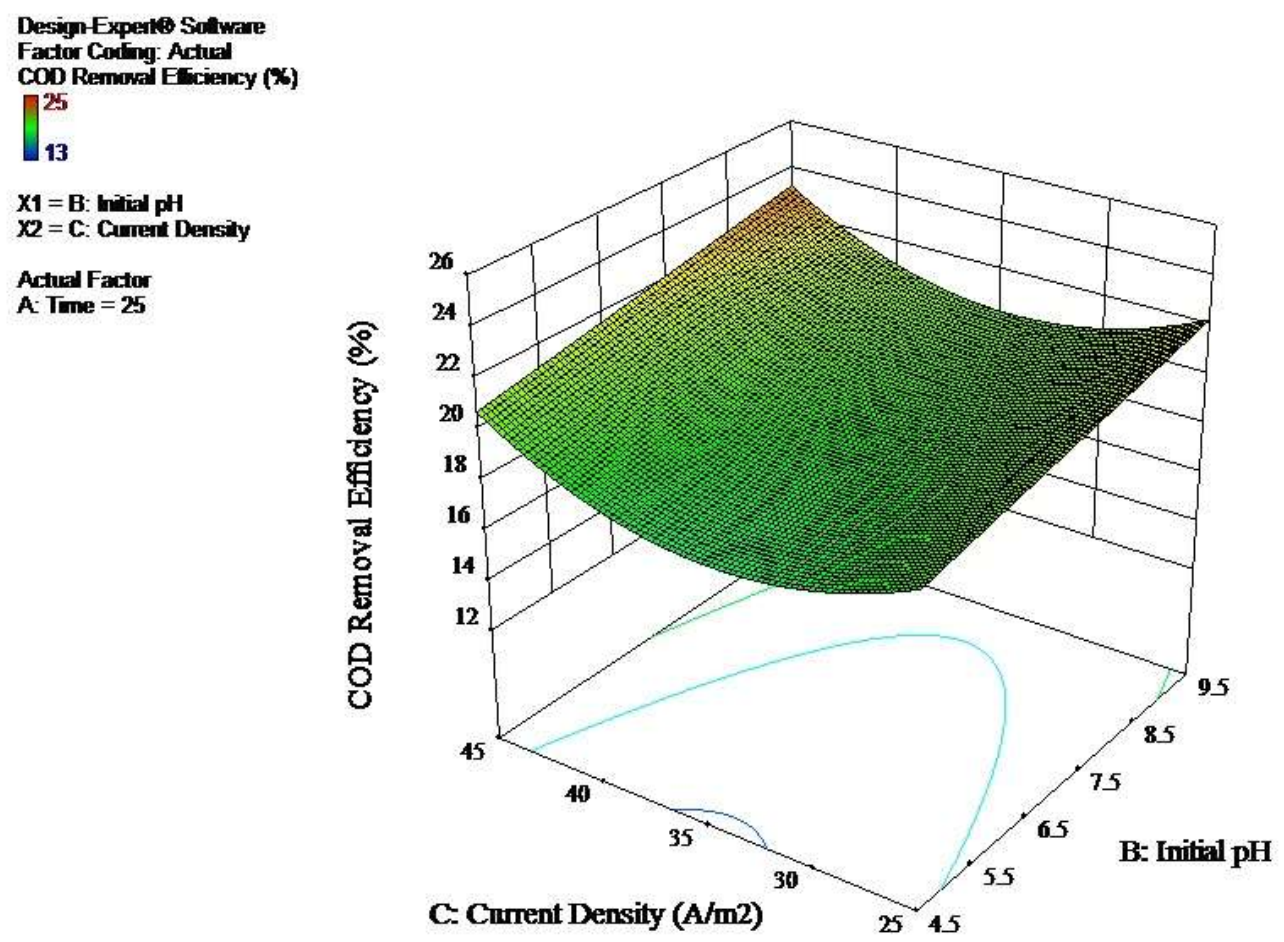

Source: Authors.

The optimization of EF process was made following five different criteria, which are shown below. Table 5 presents the outcomes of the optimization process.

Criteria 1: maximization of COD (higher than 23\%), with no restrictions regarding the factors;

Criteria 2: maximization of COD (higher than 23\%) and minimization of time;

Criteria 3: maximization of COD (higher than 23\%) and minimization of current density;

Criteria 4: maximization of COD (higher than 23\%) and minimization of $\mathrm{pH}$;

Criteria 5: maximization of COD (higher than 23\%) and minimization of time, current density and $\mathrm{pH}$.

Table 5. Optimized values - EF.

\begin{tabular}{ccccc}
\hline & \multicolumn{5}{c}{ Operational Conditions } & \\
\cline { 2 - 5 } Criteria & $\mathbf{p H}$ & Time (min) & Current Density $\left(\mathbf{A} / \mathbf{m}^{2}\right)$ & \\
\hline 1 & 9.5 & 40.0 & 45 & 26.2 \\
2 & 9.5 & 24.7 & 45 & 23.2 \\
3 & 9.5 & 40.0 & 25 & 25.2 \\
4 & 5.1 & 40.0 & 45 & 24.0 \\
5 & 6.8 & 36.8 & 44 & 24.2 \\
\hline
\end{tabular}




\subsection{Addition of Aluminum Sulfate}

Table 6 contains the operational conditions used in the tests in which EC and EF were supported by aluminum sulfate. Such conditions were defined taking into account the optimal conditions that had better performance for both COD reduction and turbidity removal.

Table 6. Optimal operational conditions used.

\begin{tabular}{cccc}
\hline Process & pH & Time (min) & Current Density $\left(\mathbf{A} / \mathbf{m}^{2}\right)$ \\
\hline EF & 6.8 & 36.8 & 44 \\
EC & 4.6 & 38.1 & 45 \\
\hline
\end{tabular}

Source: Authors.

The results obtained from the tests using concentrations of aluminum sulfate varying from $0.5 \mathrm{~g} / \mathrm{L}$ to $6.0 \mathrm{~g} / \mathrm{L}$ are presented in Figure 10. Such range of concentration values was defined based on the literature and preliminary tests. As can be observed, COD reduction efficiency suffered little changes with the addition of aluminum sulfate to the EC process. On the other hand, even little amounts of the chemical coagulant showed significant positive impacts on the treatment via EF.

Figure 10. Results from the tests with aluminum sulfate.

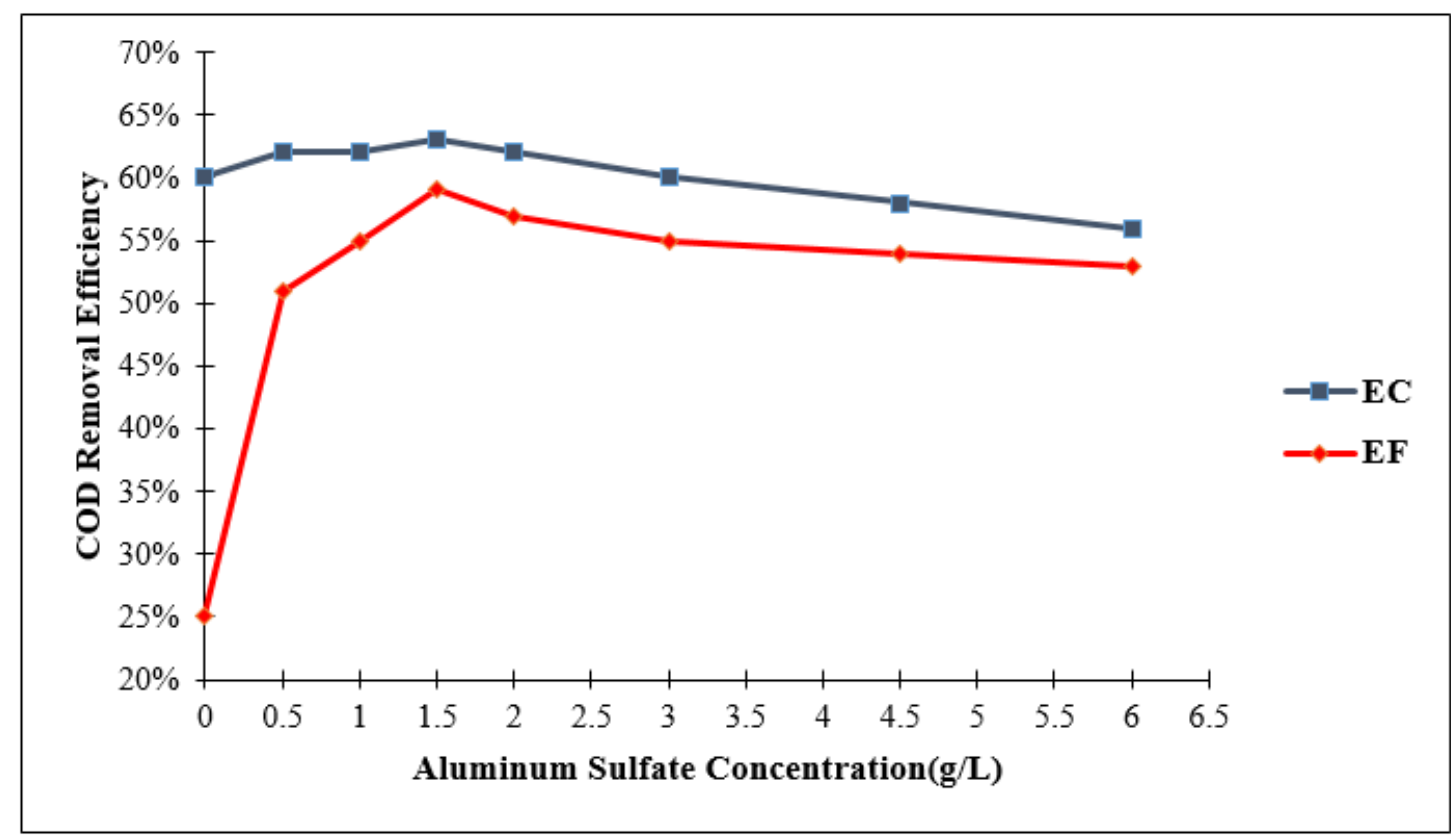

Source: Authors.

In both situations, the increase of COD removal efficiency occurs gradually until its peak, which happens when the concentration of coagulant reach $1.5 \mathrm{~g} / \mathrm{L}$. At this point, EC removed $63 \%$ of $\mathrm{COD}$ and $\mathrm{EF}$ removed $59 \%$. After this peak, nevertheless, the curves of efficiency decay, phenomena that occurs similarly in EC and EF.

The addition of aluminum sulfate also affected the turbidity removal of both electrochemical processes. In EF process, the coagulant concentration that resulted in the highest COD removal also resulted in the best turbidity removal efficiency, which was $78 \%$, value that is 1.4 times higher than the one found when treating the wastewater with no coagulant. However, it was 
observed that the addition of very high amounts of aluminum sulfate gave to the wastewater a yellow coloration.

On the other hand, the use of aluminum sulfate lowered the turbidity removal efficiency of EC. When using this chemical coagulant, the highest turbidity reduction obtained was $78 \%$, when adding a concentration of $4.0 \mathrm{~g} / \mathrm{L}$ of the product.

The addition of the chemical coagulant also affected the wastewater conductivity and, thus, the electric consumption of the electrochemical processes. Figure 11 shows the average values of voltage applied so the desired current density was maintained constant during EF and EC processes, when using different concentrations of aluminum sulfate. It can be observed that the applied voltage decreases when increasing the amount of coagulant in the wastewater, which indicates that such compound increases the conductivity of the medium.

Figure 11. Variation of medium voltage with the increase of aluminum sulfate concentration.

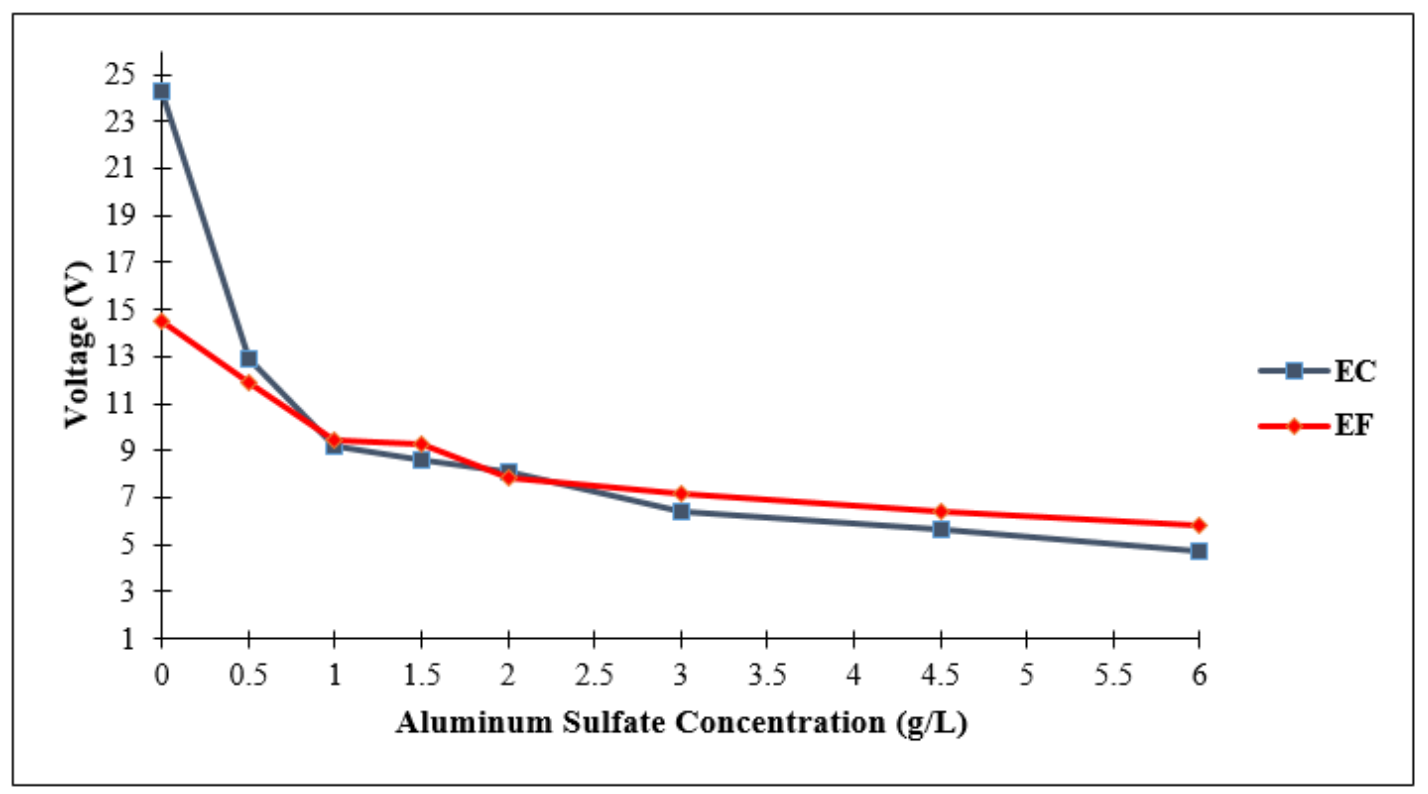

Source: Authors.

\subsection{Cost Estimate of EC and EF}

To estimate the costs of the electrochemical processes, the electrical fare of $0.1339 \mathrm{US} \$ / \mathrm{kWh}$, applied by the local electricity company Energisa (ENERGISA 2018) was considered. The price of aluminum of $6.51 \mathrm{US} \$ / \mathrm{kg}$, which was based on values that are commercially usual (exchange rate date: 07/02/2019) was also considered. Faraday's Law was used to calculate the dissolved mass of the aluminum anode. The following results were obtained:

$$
\begin{aligned}
& C O_{E F}=0.00161 \mathrm{US} \$ / \mathrm{L} \\
& C O_{E C}=0.00261 \mathrm{US} \$ / \mathrm{L}
\end{aligned}
$$

As EC has the additional cost of the aluminum consumption, its cost is higher than the cost of EF. However, it is important to highlight its highest efficiency for COD and turbidity removal, observed in this work. When combining the use of $1.5 \mathrm{~g} / \mathrm{L}$ of aluminum sulfate and the EF process, it was observed values of efficiencies close to the ones obtained in EC. Therefore, the cost of this combined treatment was also assessed, considering the additional cost of the coagulant, which was considered as being 0.09 US $\$ / \mathrm{kg}$ (Gasola et al., 2015). The following outcome was found:

$$
C O_{E F+\text { coagulant }}=0.00117 \mathrm{US} \$ / \mathrm{L}
$$

It can be noted that the use of EF in its optimal conditions combined with the addition of aluminum sulfate could be a more economically viable alternative than EC. Such advantage occurs due to the improvement of the wastewater conductivity 
when adding the chemical coagulant, what contributed to reduce the electrical consumption considerably. Moreover, it can be highlighted that the addition of aluminum sulfate not only improved COD and turbidity removal efficiencies, but also reduced the cost of EF process in $27 \%$.

\section{Conclusion}

$\mathrm{EC}$ and EF processes are compact alternatives of wastewater treatment with low detention time. In this work, these techniques were used to treat guava juice wastewater, which remarkably contains high amounts of COD and solids, as well as acid pH. The Box-Behnken experimental design was applied, and, using the software Design Expert, response surfaces, which show the influence of the factors over the response, were generated.

EC showed better results with the $\mathrm{pH}$ of 4.5 , which is close to the original condition of the studied wastewater. EF, on the other hand, had best performance with higher values of this parameter. In both cases, however, the increase of time and current density affected positively the COD reduction. The highest values of COD removal efficiency were 60\% for EC and 25\% for EF. In the tests in which such results were verified, turbidity was reduced by $88 \%$ and $56 \%$, when using EC and $\mathrm{EF}$ respectively. The tests involving the addition of aluminum sulfate showed that this coagulant had a considerable positive effect on COD and turbidity removal in the case of EF. On the other hand, such addition did not alter the performance of EC in an expressive way.

Moreover, the cost estimative of the different options of treatment revealed that, as expected, EC should be a more expensive alternative than EF. It was also verified that the addition of aluminum sulfate, as well as turning the COD and turbidity removals in EF nearly as high as the ones obtained in EC, also reduced the cost of the process. This result indicates that such combination could be a more interesting alternative to be applied to the treatment of the studied wastewater.

Taking into account the results obtained in this work, it is suggested to combine the electrochemical processes with other processes (physical, chemical or biological) in order to improve the levels of both COD and turbidity reduction efficiencies. The addition of another coagulant, for example, should favor the treatment via EC, which gave the best results. It is also recommended to investigate the influence of the addition of electrolytes to increase the conductivity of the wastewater and, thus, reduce the total cost of the electrochemical treatment options. The application of treatment on larger scales is also recommended, and the use of reactors with a layout that favors electrochemical processes should be sought.

\section{Acknowledgments}

The authors are grateful for the support granted by Coordenação de Aperfeiçoamento de Pessoal de Nível Superior (CAPES, Brazil) and Fundação de Apoio à Pesquisa e Iniciação Tecnológica do Estado de Sergipe (FAPITEC, Brazil) for providing grants, fellowships and financial support (process 88882.176516/2018-01).

\section{References}

APHA. (2005). Standard Methods for the Examination of Water and Wastewater. American Public Health Association.

Akbay, H. E. G., Akarasu, C., \& Kumbur, H. (2018) Treatment of fruit juice concentrate wastewater by electrocoagulation: Optimization of COD removal. International Advanced Researches and Engineering Journal, 2 (1), 53-57.

Álvarez, P., Pocostales, J. P., \& Beltrán, F. J. (2011) Granular activated carbon promoted ozonation of a food-processing secondary wastewater. Journal of Hazardous Materials, 185 (2-3) 776-783.

Can, O. T. (2014) COD removal from fruit-juice production wastewater by electrooxidation, eletrocoagulation and electro-Fenton processes. Desalination and Water Treatment, 52 (1-3) 65-73.

Chen, G., Chen, X., \& Yue, P. L. (2000) Electrocoagulation and Electroflotation of Restaurant Wastewater. Journal of Environmental Engineering, 126 (9). 
Research, Society and Development, v. 10, n. 2, e41910212474, 2021

(CC BY 4.0) | ISSN 2525-3409 | DOI: http://dx.doi.org/10.33448/rsd-v10i2.12474

Chen, G. (2004) Electrochemical technologies in wastewater treatment. Separation and Purification Technology, 38 (1) 11-41.

Chen, G., \& Hung, Y. (2007) Electrochemical Wastewater Treatment Processes. In: Wang L. K., Hung Y. T., Shammas N.K. (eds) Advanced Physicochemical Treatment Technologies. Handbook of Environmental Engineering, vol 5. Humana Press.

Comninellis, C., \& Chen, G. (Ed.) (2010). Electrochemistry for the Environment. Springer.

Drogui, P., Asselin, M., Brar, S. K., Benmoussa, H., \& Blais, J. F. (2008) Electrochemical removal of pollutants from agro-industry wastewaters. Separation and Purification Technology, 61, (3) 301-310.

Gasola, D. L., Maquezi, S. L., \& Azzolini, J. C. (2015). Comparação entre o uso do sulfato de alumínio e do hidroxicloreto de alumínio no tratamento de água para geração de vapor. Unoesc \& Ciência, 6 (1):7-18.

Kuokkanen, V., Kuokkanen, T., Rämö, J., \& Lassi, U. (2013) Recent Applications of Electrocoagulation in Treatment of Water and Wastewater - A Review. Green and Sustainable Chemistry, 3 (2) 89-121.

Moussa, D. T., El-Naas, M. H., Nasser, M., \& Al-Marri, M. J. (2017) A comprehensive review of electrocoagulation for water treatment: Potentials and challenges. Journal of Environmental Management, 186 (1) 24-41.

Pereira, A. S. et al. (2018). Metodologia da pesquisa científica. UFSM. https://repositorio.ufsm.br/bitstream/handle/1/15824/Lic_Computacao_MetodologiaPesquisa-Cientifica.pdf?sequence $=1$.

Sahu, O., Mazumdar, B., \& Chaudhari, P. K. (2014) Treatment of wastewater by electrocoagulation: A review. Environmental Science and Pollution Research, 21 (4), 2397-2413.

Wang, L.K., Shammas, N. K., Selke, W. A., \& Aulenbach, D. B. (Eds.) (2010) Flotation technology. Humana Press. 